\title{
HUMANISTIC APPROACH IN ACTION: EFL WRITING CLASS
}

\author{
Soviyah \\ Universitas Ahmad Dahlan, Yogyakarta
}

\begin{abstract}
After finishing secondary education level, one can hardly expect that he will be able to perform well in English. One cause is that it is assumed that English learning process emphasizes more on the students cognitive rather than on their psychical needs as human beings. Teachers tend to ignore what's the so called education from the neck up. Based on the writer's personal experience during her schooling phase, this paper, therefore tries to offer English teachers the humanistic approach applied in an EFL writing class. This approach is worth considering since its main principle is bringing the learning process towards a more affective situation by combining the subject matter to be learned with the feelings, emotions, experiences, and lives of the students. In this paper, the discussion of what humanistic approach is and why it is worth considering especially in a writing class are elaborated in details. In addition, a model of a classroom application will also be given.
\end{abstract}

Key words: humanistic approach, writing.

Up to now I have been working with English for more or less twenty years, and an interesting phenomenon happened during that period. I was curious to know what caused it and what solution to take. The two curiosities are the factors I consider lying behind this writing that have driven me to write this paper finally.

I started 'getting in touch' with English for the first time when I entered junior high school. What I remember about it is that it was a structure and grammar class in which I had to memorize piles of verb changes i.e. from present to past, past to participle, and a series of tenses formulas. I could write one or two sentences under some certain given structures at that time but I knew 
nothing about those sentences. I did not have any picture about what they meant exactly, when and where to use them appropriately and how to say them correctly as well. I could only say that none of my English macro skills developed during that period. I could not perform a simple English conversation neither could I write a simple English letter in spite of the three years I had spent studying it.

Unfortunately, such a condition repeatedly occurred when I forwarded my study in senior high school for the next three years. The 'label' was written English with students active learning or $C B S A$ approach, yet the learning activities were very much like the ones I found in my junior high school. Yet, there was a surprising thing emerged during my two schooling periods above. It was my English mark that was always extremely good despite the communicative disability feeling I had. Since then, I felt that there would be something wrong with the learning process when it focused more on the structure.

Soon after finishing my secondary education I noticed that I started being able to speak and write in English. It was when I entered university taking English as my major. Among four English macro skills, writing was the one that I found it most difficult. In my opinion, there were two causes that, at least, had contributed to this. The first and the most important one was that the class activity was very typical - if 'dull' is considered sarcastic to use in this context. The lecturer usually started the writing chores with reading the book, explaining a little and ended the class by asking us to write a writing under given time. No other activities but writing under pressure every time there was a writing class. The next cause was the way lecturer appreciated our works. As a common practice, the writing we made would be corrected and then given back to us so that we could revise them. At a glance it was not a problem at all for it was a common thing in writing context. What made this stage be a discouraging effect triggering the loss of our writing motivation was that all that the lecturer did at this point was correcting only the grammar and structure of our works by putting some red circles and crosses on the sentences we wrote. Never had she given appreciation upon our genuine ideas in the form of comments or other appreciative words as a respond to the content of our writing. As a result, we learnt to feel that we were not seen as a human being having mind since the feeling and thought we expressed through our writings were appreciated only on the basis of their structure correctness. This kind of feeling was surely one of the contributing factors that had led me to find writing as a difficult and unenjoyable subject.

I am now an English lecturer of English education department teaching stu- 
dents with heterogeneous English levels. I regularly handle some writing classes in every semester ranging from the lowest writing level to the upper ones. Once I ever asked the students to give their opinions about English macro skills. To my surprise, most of them wrote that writing was the most difficult subject compared to the other three. This finding was surprising and a bit shocking to me. Knowing that my students felt what I had felt when I had been a student was not something that I expected to happen. Since then I give greater concern in the writing matter. And aided with important lesson I derived from my past schooling period, I have been trying to adopt, modify, and develop various materials and learning activities as well as teaching approach and apply them in my writing classes. One of them which I see the one that my students like most and enjoy to engage in is humanistic approach. It is the purpose of this paper then to give an account of humanistic approach applied in EFL writing class and to present a classroom application as well. Hopefully this little writing could be a small but inspiring thing to any English teachers.

\section{NOTES ON HUMANISTIC APPROACH}

\section{Humanistic Approach}

Parkay (1998) states that the term humanistic is derived from the philosophy of humanism and developed during the European Renaissance and Protestant Reformation. Humanistic psychology emphasizes personal freedom, choice, awareness, and personal responsibility. As the term implies, it also focuses on the achievements, motivation, feelings, actions, and needs of human beings. The goal of education, according to this orientation, is individual self-actualization.

In line with the above definition, Maslow (1962), one of the fathers in humanistic psychology, in Parkay (1998) also states that humanistic teaching's goal is to enhance students' achievement of their full potential through selfactualization.

The two statements above show that humanistic education is a process of teaching and learning where the main goal is students' self actualization as human beings. Students are believed to control their own destinies through the application of their intelligence and learning. Students are viewed more as individuals who have personal choices, motivations, feelings, needs, achievement, and responsibilities.

Moskowitz (1981) in her famous humanistic book Caring and Sharing in 
the Foreign Language Classroom says that humanistic education recognizes that it is legitimate to study oneself. The content relates to the feelings, experiences, memories, hopes, aspirations, beliefs, values, needs and even fantasies of the students. It is a two-way street education which strives to integrate the subject matter and personal growth dimensions of the students.

Based on those statements, it can be summarized that humanistic approach is a way of teaching where the students' self-actualization is the primary goal. Students are viewed as human beings who have feelings, emotions, beliefs, values and responsibilities and teachers are to give them trust and respect climate to express those in the classroom so that they can optimize the best of themselves. In addition, it combines the subject matter taught with the personal dimensions of the students in order that the students can feel free, relaxed and unthreatened during the teaching process.

The effects of this approach on students are very significant. This approach will lead students to be successful in learning a language since they are able to express themselves in the target language more easily because the teacher gives them trust and respect to express what they feel and thought and share it with their friends in the target language. Students seem unaware that they are to study the language since the activities and materials are closely related to their feelings and lives. Some experts illustrate them as follows:

Maslow (1987) says that humanistic teaching believes that learner's state of mind and personal response to the activity of learning is central to the success or failure in language learning. Some other theorists in Harmer (2001) agree with this. They write that humanistic teaching has a basic belief that the learner's feelings are as important as their mental or cognitive abilities. If students feel hostile towards the subject of the study, the materials, or the teaching methods, they will be unlikely to achieve much success. And humanistic approach can counter this unbeneficial situation (Stevick 1996).

\section{Basic Principles of Humanistic Education}

Moskowitsz (1981) lists some basic principles of humanistic education. They are as follows: (1) A principal purpose of education is to provide learning and an environment that facilitate the achievement of the full potential of the students; (2) Personal growth as well as cognitive goal is a responsibility of the school. Therefore education should deal with both dimensions of humans - the cognitive or intellectual and the affective or emotional; (3) For learning to be 
significant, feelings must be recognized and put to use; (4) Significant learning is discovered for oneself; (5) Human beings want to actualize their potential; (6) Having healthy relationships with other classmates is more conducive to learning; (7) Learning more about oneself is a motivating factor in learning; (8) Increasing one's self-esteem enhances learning.

An important point underlying these principles is that these principles are essential assumptions of humanistic education. They are the principal bases on which every humanistic learning activity is built. In relation to foreign language teaching setting, it means that it is very important for every teacher and teaching material designers to base the building of language programs along these basic principles. By so doing, the learning activities will be truly motivating for the students and enable teachers to do justice to their students as human beings which is essential to humanistic teaching.

\section{APPLYING HUMANISTIC APPROACH}

\section{Teacher's Role}

Similar to conventional teaching, humanistic teaching believes that teachers hold important roles during the learning process. The difference is that humanistic teaching defines that the most essential role of a teacher is as a facilitator for her students as stated by Rogers (1982) in Parkay (1998). He explains that teachers have an important role in humanistic classroom and calls it as "facilitator". Teachers should believe in students and at the same time respect them as individuals. And the classroom should be a place "in which curiosity and natural desire to learn can be nourished and enhanced". Humanistic teachers encourage students to learn and grow through their nonjudgmental understanding of their students.

Maslow (1962) also agrees with that idea. He explains that, in humanistic classroom, the role of teachers is not to force students to learn; instead, teachers should create a climate of trust and respect. Teachers should allow students to decide what and how they learn, to question authority, and to take initiative in "making themselves".

Under this role as facilitator teachers have two sub-roles in the class. First, teachers should build a climate of acceptance and trust. It is very essential for teachers to establish a warm, supportive, accepting and nonthreatening climate. Only under this kind of atmosphere that students feel comfortable to express 
themselves in the target language. We have to remember that every time students attempt to speak the foreign language, they are taking risk - that their grammar will not be accurate, that they will be corrected, that the class will laugh. Therefore, it is very crucial for students to feel that they will not be made fun of what they share. One way to build such a climate in the class is by setting ground rules. At the beginning of every activity teacher and students should set ground rules every body - including the teacher - in the class must obey. It will be better if the rules are written on the board so that every body in the class can remember them continuously. The rules are (1) Everyone in the class gets listened to; (2) No put-downs. Every body should not tease or laugh at anyone who shares; (3) The right to pass. Turn passing is $\mathrm{OK}$ as long as the reason is clear enough, but no passes due to the reason that student does not know how to say something in English.

The second sub-role is helping students perform in English. Teachers should always be aware that applying humanistic approach does not mean putting the subject aside. English is still the main concern and teachers can do that under the humanistic approach successfully, indeed. Teachers can help students perform in English by giving them abundant vocabulary and grammar supply, tolerating students' errors and inhibition, and helping students anytime they need help with the language so that they will not revert to their native language every time they cannot use English.

\section{The Activities}

\section{Type}

Most of learning activities under humanistic approach are discussion and students' involvement activities. Those activities are intended to be done in small groups. The group can be as small as two or three or as large as seven or eight. Small groups will allow maximum participation and involvement of the students in using English and in getting the most out of the activity. Besides, small groups will save time with activities and each student has several turns or is requested to respond at length.

\section{Material}

Actually there is no single material which is independently humanistic in nature. Humanistic approach is a way of teaching, a set of techniques that can be used to get students comfortable and confident to study the language. It means 
that teachers do not need to provide brand new materials, they can still use materials they already have instead. Humanistic approach can be included to supplement, review, and introduce the existing materials. What teachers have to do is just fitting them in. One way to fit humanistic materials in is by adding some humanistic questions and techniques in them. It is so simple. An example may illustrate this.

When the class is going to write a descriptive paragraph/essay telling about family, a teacher usually does pre-teaching activities in order to gear students to the topic before they do writing. The teacher usually gives the class questions as the lead-in activities. Such questions asked are as "How many brothers and sisters do you have?" or "What is your father?" or "What furniture is in your bedroom?". These questions are appropriate already, but are not humanistic. Simply change the questions by taking them deeper into "How does it feel to be the oldest (youngest or middle) child?" or "What advantages and disadvantages are there?" or "What special object do you display in your room that gives you memories?" and so on, and the lead-in activities become the humanistic ones.

To sum up, providing "humanistic materials" is not uneasy. Teachers can do it by including affective purposes and techniques into the materials in addition to the linguistic or cognitive purposes they have set previously.

\section{Topic}

As explained in the previous section, humanistic approach is combining the subject matter taught with the students' personal dimensions. The topics introduced should not then be out of this area. Moskowitsz ( 1981 ) says that the topic's focus must be on students' area of awareness. The categories can be about: (1) Relating to others; (2) Discovering myself; (3) My strengths; (4) My self image; (5) Expressing my feelings; (6) My memories; (7) Sha-ring myself; (8) My valuesi; (9) The arts and me; and (10) Me and my fantasies.

In practice, teachers must divide each of those categories into some subcategories and topics so that each teacher may have different numbers of topics. It depends on teacher's creativity. The next thing is suiting the level of the students. The categories listed above are basic. Teachers have to suit the level and design activities which best fit the students' language level, therefore the same category and same topic can be formed into different activities depending upon to whom it will be given.

There is one thing, however, that teachers have to keep in mind, i.e. teach- 
ers should accentuate the positive topics and avoid the negative ones. Teachers are highly suggested that they present positive topics since positive topics can encourage students to see the best sides of them, increase their self-acceptance, find their self-identity and accept others as well. This will make them feel confident and motivated to communicate during the learning process. On the contrary, giving negative topics may hurt students and lead them to focus on their negative sides and finally they will underestimate themselves. Therefore, negative topics like the followings are not suggested to introduce.

Something I wish had never happened

What I dislike about myself

My saddest memory

My worst failure

The most embarrassing moment in my life

Teachers should change those kinds of themes and reverse to the positive ones. Note the changes!

Something I'm glad happened

What I like about myself

My happiest memory

My greatest success

A time when I feel proud of

\section{A Model of Classroom Application}

This section will show a simple sample of classroom application.

Category : Discovering Myself

Topic : People are different

Sub topic : I like you - you are different

\begin{tabular}{|l|l|}
\hline Affective purpose & $\begin{array}{l}\text { Students are hoped to be able to identify their dif- } \\
\text { ferences from their friends and how they feel } \\
\text { about it and accept others as well. }\end{array}$ \\
\hline Linguistic purpose & $\bullet$ Vocabulary : Terms expressing personalities \\
\hline
\end{tabular}




\begin{tabular}{|l|l|}
\hline & $\begin{array}{l}\text { - } \text { Grammar : Simple sentence writing } \\
\text { S+Vbe+Adj } \\
\text { - }\end{array}$ \\
\hline Level & Beginner, pre intermediate \\
\hline Size of group & Whole class, group of two \\
\hline Materials needed & Small cards \\
\hline Procedures & $\begin{array}{l}\text { Teacher leads the students into the material by } \\
\text { giving orientation "We often feel it's impor- } \\
\text { tant to be like other people and we feel wor- } \\
\text { ried we're different. Sometimes it's OK to feel } \\
\text { that way but it's also very important to be } \\
\text { proud of our differences". } \\
\text { Teacher tells the class some things about her } \\
\text { that make her different and her feeling about it } \\
\text { "I won a silver medal in a Javanese singing } \\
\text { contest", or "I am a humorous person", etc. } \\
\text { This is to give them an example. } \\
\text { Each student is asked to write down three } \\
\text { things she/he feels good about him/her that } \\
\text { make him/her different on a small card and } \\
\text { write his/her name on it. } \\
\text { After students have finished, teacher collects } \\
\text { the cards, reads them aloud, and other students } \\
\text { guess who each person is. This is done until } \\
\text { all cards are read (if possible). } \\
\text { Next, teacher asks the class some follow-up } \\
\text { questions to help them remember their differ- } \\
\text { ences such as "Who remembers something } \\
\text { about someone in the class?". Students are } \\
\text { expected to make responds like "Ahmad lived } \\
\text { in Aceh", "Dewi has two cats" and so on until } \\
\text { the whole class know and remember the dif- } \\
\text { ferences each of their friends in the class has. } \\
\text { This is intended to make all students in the } \\
\text { class know their differences and accept those } \\
\text { of their friends. }\end{array}$ \\
\hline
\end{tabular}




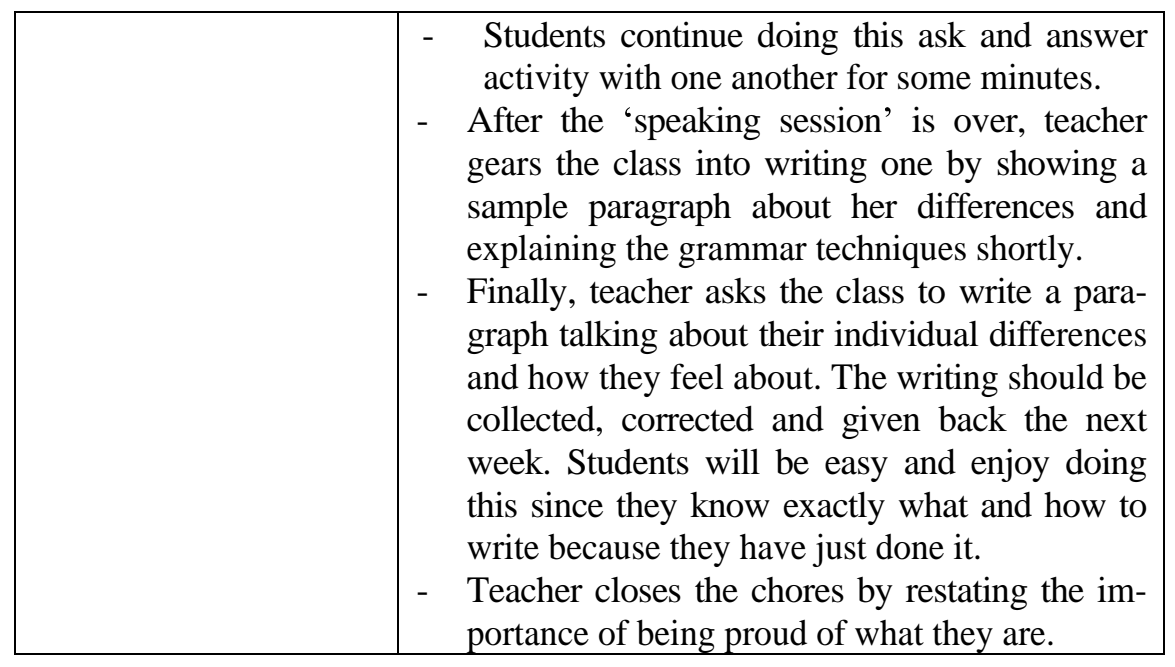

\section{CLOSING}

The above explanation is not yet complete actually. Its primary intent is attempting to offer English teachers an alternative so that they will be more aware that their main duty is not merely teaching English but also fostering the students' psychological dimensions. And it is not difficult to do since to teach the two can be done at the same time. However, it does not mean that humanistic approach is free from criticism. Some are questioning and worried about how appropriate is it to have the teacher encouraging students' personal revealing, how well are teachers able to deal with such activities? How culturally appropriate is it, etc. Yet, all English teachers agree that using the students themselves as the topic in EFL classrooms may help them reduce the 'unjuicy nature' of English study.

\section{REFERENCES}

Harmer, J. 2001. The Practice of English Language Teaching $-3^{\text {rd }}$ ed. England: Longman.

Maslow, A. 1962. Motivation and Personality. New York: Basic Books.

Maslow, A. 1987. Motivation and Personality $-3^{\text {rd }} e d$. New York: Harper and Row. 
158 TEFLIN Journal, Volume 18, Number2, August 2007

Moskowitsz. 1981. Caring and Sharing in the Foreign Language Classroom$4^{\text {th }}$ ed. USA: Newburry House.

Parkay, F. W. 1998. Becoming a teacher $-4^{\text {th }}$ ed. USA: Allyn \& Bacon

Rogers. 1982. Freedom to learn in the Eighties. Columbus, OH: Charles E Merril.

Stevick, E. 1996. Memory, Meaning and Method: Some Psychological Perspectives on Language Learning. USA: Heile and Heinle. 